\title{
Pharmaceutical clinical services in basic care in a region of the municipality of São Paulo
}

\author{
Felipe Tadeu Carvalho Santos ${ }^{1 *}$, Dayde Lane Mendonça da Silva², Noemia Urruth Leão Tavares ${ }^{1,2}$ \\ ${ }^{1}$ Postgraduate Program in Collective Health, Faculty of Health, University of Brasilia (UnB), Brasilia, Brazil, ${ }^{2}$ Department of \\ Pharmacy, Faculty of Health Sciences, University of Brasilia (UnB), Brasilia, Brazil
}

\begin{abstract}
Pharmaceutical care has undergone several transformations in the health context over the years. Thus, the pharmacist has suffered a reconfiguration of his performance, mainly with the incorporation of clinical services and patient approach. The study analyzed the results of the implementation of pharmaceutical clinical services in Primary Health Care, through the use of indicators of supply, demand and productivity, clinical and process quality related to pharmaceutical care. We included all the clinical visits $(n=1,833)$ performed to 1,080 users in 12 Basic Health Unit facilities from May to November 2016, of which $40.8 \%(n=748)$ were consultations in the establishments and 50.2\% ( $n=1,085)$ home visits. Most patients $(73.5 \%)$ were referred by team and $17.5 \%$ were captured through active search. Of the total workload, $12.5 \%$ were dedicated to pharmaceutical consultations and $20.0 \%$ to home visits. In total, we identified 3,078 pharmacotherapy-related issues, an average of 2.8 per patient, and 6,882 pharmaceutical interventions were performed, equivalent to 6.3 interventions per patient. The problem with adherence to pharmacotherapy and the intervention of medication counseling were the most found. Results reinforce the importance of pharmaceutical clinical services in identifying the control of the most prevalent health conditions and monitoring the therapeutic results associated with drug use.
\end{abstract}

Keywords: Pharmaceutical care/primary care. Chronic health/conditions. Pharmacists/professional practice/Brazil.

\section{INTRODUCTION}

Pharmaceutical care is an important field in the health area and has been mostly understood as a bureaucratic management process involving technologies aimed at medicines logistics (Araújo, Freitas, 2006). The activities related to the clinic and the use of drugs are still a challenge for the country, especially regarding the performance of the pharmacist in the management of patient care with the multiprofessional team.

With the transformations of health technologies and services throughout the $20^{\text {th }}$ century, the pharmacist's role and functions have become the focus of intense debate, especially in the United States and Europe, with some repercussions in Latin America in order to strengthen the performance of services provided by this professional to the health care network users (Funchal-Witzel et al.,

\footnotetext{
*Correspondência: F. T. C. Santos. Faculdade de Ciências da Saúde, Universidade de Brasília (UnB), Brasília, Brasil, Asa Norte, CEP: 70.910-900, Brasília/ DF. Telefone: 551197981 1400. E-mail: felipescarvalho@yahoo.com.br
}

2011). Roberts et al. (2003) highlights notable changes in pharmacy practice with a focus mainly on the provision of care services. The pharmacist is even included as a professional focused mainly on the performance that involves information and training on the use of drugs (Loch-Neckel, Crepaldi, 2009).

As described by Oliveira et al. (2005), some studies show that an effective performance of the pharmacist with the patient and integrated with the health team contributes systematically to a more effective drug treatment aiming at achieving positive therapeutic results. Despite this, there are several barriers to the dissemination of pharmaceutical clinical services, which are similar in countries regardless of the socioeconomic situation and the developed pharmacy model (Gastelurrutia et al., 2005).

Thus, comprehensive care in the complex health system, as well as teamwork with an emphasis on the Unified Health System (SUS) address the social needs of the pharmacist in today's society. This professional then begins to incorporate new care strategies into his work routine by developing clinical services offered to the 
population, through the development of user counseling actions, pharmacotherapy review, drug reconciliation, evaluation and promotion of therapeutic adherence and pharmacotherapeutic follow-up (Brasil, 2014a). These actions are materialized through the realization of specific and shared consultations, home visits and educational actions geared to the community, which occur mainly in the scope of primary health care.

In view of the above, the development of studies that show the impact of pharmaceutical clinical consultations on public health, targeting various lines of care developed in primary health care (PHC) and people's quality of life is gaining significance. This study aimed to analyze the preliminary results of the implementation of clinical services performed by pharmacists in $\mathrm{PHC}$ in a region of the city of São Paulo, using supply, demand and productivity indicators of these services, as well as process indicators and clinical indicators that evidence patients' health conditions.

\section{METHODOLOGY}

This is a retrospective descriptive study with a quantitative methodological approach in which data from clinical consultations performed by pharmacists working in 12 PHC with the Family Health Strategy (ESF) modality of the Eastern Regional Health Coordination, in the Technical Health Supervision of the Itaim Paulista region in the municipality of São Paulo, which implemented pharmaceutical clinical services during the study period.

The Itaim Paulista region is located in the extreme east of the city of São Paulo and consists of a total of approximately 380,000 inhabitants, according to the 2010 Census (São Paulo, 2016a). It is one of the most populous regions of the city, has a low level of family income, with a predominance of up to two minimum wages, as well as a low schooling population profile (Varela, Matsumoto, 2012). Overall, 19 pharmacists work in PHC services. Regarding health equipment, it has 15 UBS, of which 12 are of the ESF modality, as well as a health surveillance center, three Psychosocial Care Centers (CAPS) and three urgent and emergency care facilities. It also has two physical rehabilitation centers and one day-hospital, called Rede Hora Certa, as well as one medium-sized regional hospital. (São Paulo, 2016b).

The pharmaceutical clinical services investigated were implemented and institutionalized based on a project conducted by the Santa Marcelina Social Health Organization in partnership with the Itaim Paulista Health Technical Supervision in the year 2016, which included the training and follow-up of pharmacists in the territory. Each UBS has a pharmacist with a workload of 40 hours of work a week.

We included in the study data from all pharmaceutical clinical services performed through consultations and home visits at the UBSs that implemented clinical services in the period from May 2 to November 30, 2016, which correspond to the first seven months of service implantation in the PHC of the region, being therefore preliminary data of the study.

Patient eligibility criteria for pharmaceutical clinical service in the region were defined jointly with the health team: use of 5 or more drugs, having two or more chronic comorbidities and a suspected pharmacotherapy-related problem. Any professional could make the referral of the user to the pharmaceutical service, according to established criteria.

The variables used to characterize the profile of the users served in the pharmaceutical clinical services were: sex (male or female), age range (between 0 and 20, 20 and 40, 40 and 60, over 60 years), use of alcoholic drink (yes or no), use of tobacco currently (yes or no), perform some physical activity (yes or no), difficulty in using medications (yes or no) and has a caregiver (yes or no).

Services performed for patients who moved to another area, that is, UBS of reference, during the defined period for data collection were excluded from the analysis, as were consultations and home visits performed for patients who died or abandoned the service (care refusal).

The service database used a data collection source, which consolidated the information from the pharmaceutical services with data from the programmed schedule of the professional, the production sheet and clinical care records. Consultation forms and home visits were used (Brasil, 2014b).

Indicators related to supply, demand and productivity of services as described in Figure 1 were built for the analysis of pharmaceutical clinical services.

As a complement, we analyzed during the study period process and clinical indicators of consultations performed, according to Figure 2. Pharmacotherapyrelated problems were identified through the patient's anamnesis and pharmacotherapy review, in which real or potential drug-related problems were identified, and the following pharmacotherapy-related groups of problems categorized from the services were considered in the analysis according to the classification used in the Pharmaceutical Care Project in Basic Health Care of the Health Ministry (Brasil, 2014b), in: problems related to drug selection and/or prescription, problems 


\begin{tabular}{|c|c|c|}
\hline \multicolumn{2}{|r|}{ INDICATOR } & CALCULATION \\
\hline \multirow{5}{*}{ 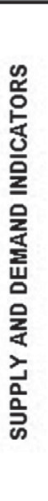 } & $\begin{array}{l}\text { Average number of monthly hours available } \\
\text { for pharmaceutical consultations }\end{array}$ & $\begin{array}{l}\text { Average number of monthly hours available in } \\
\text { the pharmacist's schedule for consultations / } \\
n^{0} \text { of months }\end{array}$ \\
\hline & $\begin{array}{l}\text { Average number of monthly hours available } \\
\text { for pharmaceutical home visits }\end{array}$ & $\begin{array}{l}\text { Average number of monthly hours available in } \\
\text { the pharmacist's schedule for home visits / } \\
n^{0} \text { of months }\end{array}$ \\
\hline & $\begin{array}{l}\% \text { of patients seen by the pharmacist and } \\
\text { referred by the team }\end{array}$ & $\begin{array}{l}\text { (Number of patients seen by the pharmacist } \\
\text { referred by the team / Total number of } \\
\text { patients seen by the pharmacist) } X 100\end{array}$ \\
\hline & $\begin{array}{c}\% \text { of patients seen by the pharmacist } \\
\text { originating from self-referrals }\end{array}$ & $\begin{array}{l}\text { (Number of patients seen by the pharmacist } \\
\text { originating from self-referrals / Total number } \\
\text { of patients seen by the pharmacist) } X 100\end{array}$ \\
\hline & $\begin{array}{l}\% \text { of patients seen by the pharmacist } \\
\text { originating from active search }\end{array}$ & $\begin{array}{l}\text { (Number of patients seen by the pharmacist } \\
\text { originating from active search / Total number } \\
\text { of patients seen by the pharmacist) } \times 100\end{array}$ \\
\hline \multirow{4}{*}{ 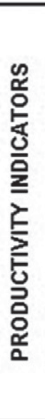 } & $\begin{array}{l}\text { Average number of pharmaceutical } \\
\text { consultations performed for the month }\end{array}$ & $\begin{array}{l}\text { Total number of pharmaceutical } \\
\text { consultations performed } / \mathrm{n}^{0} \text { of months }\end{array}$ \\
\hline & $\begin{array}{l}\% \text { patients non-attendance at } \\
\text { pharmaceutical consultations }\end{array}$ & $\begin{array}{l}\text { (Total number of non-attended } \\
\text { pharmaceutical consultations / Total } \\
\text { scheduled pharmaceutical consultations) X } \\
100\end{array}$ \\
\hline & $\begin{array}{c}\text { Average number of pharmaceutical home } \\
\text { visits performed for the month }\end{array}$ & $\begin{array}{l}\text { Total number of pharmaceutical home visits } \\
\text { performed } / n^{0} \text { of months }\end{array}$ \\
\hline & $\begin{array}{c}\% \text { of patients who refused or not and who } \\
\text { were at home for home care }\end{array}$ & $\begin{array}{l}\text { (Total number of patients who refused or not } \\
\text { and who were at home for pharmaceutical } \\
\text { home care / Total number of scheduled } \\
\text { pharmaceutical home visits and } \\
\text { consultations) X } 100\end{array}$ \\
\hline
\end{tabular}

FIGURE 1 - Indicators related to supply, demand and productivity of pharmaceutical clinical services in PHC.

\begin{tabular}{|c|l|}
\hline \multicolumn{1}{|c|}{ INDICATOR } & \multicolumn{1}{c|}{ CALCULATION } \\
\hline $\begin{array}{c}\text { Average number of pharmacotherapy- } \\
\text { related problems identified by patient for } \\
\text { the period }\end{array}$ & $\begin{array}{l}\text { Total number of pharmacotherapy-related } \\
\text { problems identified in home pharmaceutical } \\
\text { consultations and services / Total number of } \\
\text { patients seen in home pharmaceutical } \\
\text { consultations and services }\end{array}$ \\
\hline $\begin{array}{c}\text { Average number of pharmaceutical } \\
\text { interventions per patient for the period }\end{array}$ & $\begin{array}{l}\text { Total number of pharmaceutical interventions } \\
\text { performed in home pharmaceutical } \\
\text { consultations and services / Total number of } \\
\text { patients seen in home pharmaceutical } \\
\text { consultations and services }\end{array}$ \\
\hline $\begin{array}{c}\% \text { of patients with diagnosis of health } \\
\text { condition in controlled clinical status }\end{array}$ & $\begin{array}{l}\text { (Number of patients with diagnosis of health } \\
\text { condition in controlled clinical status) / (Total } \\
\text { number of patients with diagnosis of health } \\
\text { condition) X } 100\end{array}$ \\
\hline $\begin{array}{c}\% \text { of patients with diagnosis of health } \\
\text { condition in unknown clinical status }\end{array}$ & $\begin{array}{l}\text { (Number of patients with diagnosis of health } \\
\text { condition in non-controlled clinical status) / } \\
\text { (Total number of patients with diagnosis of } \\
\text { health condition) X } 100\end{array}$ \\
\hline $\begin{array}{l}\text { (Number of patients with diagnosis of health } \\
\text { condition in unknown clinical status) / (Total } \\
\text { number of patients with diagnosis of health } \\
\text { condition) X } 100\end{array}$ \\
\hline
\end{tabular}

FIGURE 2 - Process and clinical indicators of patients seen in clinical pharmaceutical services of Primary Health Care.

of administration and/or adherence by the patient to pharmacotherapy, problems of drug discrepancy between levels of care, problems in dispensing the medication, problems in monitoring the health condition and that involve drug safety (adverse reaction and poisoning).
Interventions were considered to be the conduct performed by pharmacists at each clinical care, such as advice on medications or non-pharmacological measures, drug therapy change or suggested change, recommendation for monitoring to assess the clinical 
status of patients' health conditions, referrals to others professionals and provision of materials for dosage orientation (Brasil, 2014b).

Indicators (Figure 2) of hypertensive and diabetic users, as verified by the patient's diagnosis in the medical records due to the prevalence of such health conditions were analyzed to assess the control profile of the clinical status of health conditions of patients treated in the first three months of the implementation of pharmaceutical clinical services.

The evaluation performed at the clinic took into consideration the clinical and laboratory parameters, such as residential blood pressure, capillary glycaemia and glycated hemoglobin monitoring, according to hypertension and diabetes protocols and clinical guidelines (Sociedades Brasileiras de Cardiologia, Hipertensão e Nefrologia, 2011; Sociedade Brasileira de Diabetes, 2015). Thus, patients were categorized by scope of the established therapeutic goals, in: controlled, when goals were achieved at that moment; non-controlled, indicating that problem is not under control and non-achievement of therapeutic goals; and unknown, where, due to the lack of clinical and laboratory parameters, it was not possible to define the comorbidity control profile at that moment.

The analysis of the results was performed by descriptive statistical inference, where measures of central tendency and variability and simple and relative absolute frequencies, supported by the system for statistical analyzes of the Epi Info ${ }^{\mathrm{TM}}$ 7.1.5 program were calculated.

Access to the database was made available through authorization by the competent authority of the Municipal Health Secretariat of São Paulo and information was aggregated without individual identification. According to Resolution $\mathrm{N}^{\mathrm{o}} 510 / 2016$, it was exempted from the evaluation of the Research Ethics Committee (CEP).

\section{RESULTS}

We analyzed data on consultations and home visits performed by pharmacists in 12 UBS that implemented the clinical services during the study period. In this time bracket, 1,080 users were attended, totaling 1,833 visits, of which $40.8 \%(n=748)$ were consultations in health facilities and $59.2 \%(\mathrm{n}=1,085)$ were home visits. Of the total number of attendances, a large part (59\%) corresponded to first-time attendance and the other to returning visits, which ranged from one to six returning visits in the period.

Females were the predominant profile of users serviced in pharmaceutical clinical services, with $71 \%$ $(n=767)$, and 60 years and over, with $63 \%(n=681)$. Of the total, $92 \%(n=994)$ reported not having consumed any type of alcoholic beverages, $86 \%(n=929)$ were not smokers and only $12 \%(n=130)$ exercised at least three times a week in the care period. While $40 \%(n=432)$ had difficulty in conducting drug treatment autonomously, only $21 \%(n=227)$ had a caregiver for health care and drug administration assistance.

Regarding the profile of pharmacists, all the participants worked in a UBS with a 40-hour weekly workload. In the implementation of the service, the pharmacist's activities were distributed in a fixed weekly schedule, standardized in all facilities, where $40.0 \%$ $(\mathrm{n}=16)$ of the workload was logistical and administrative activities, 42.5\% $(\mathrm{n}=17)$ clinical assistance activities and $17.5 \%(n=7)$ technical-pedagogical activities of interaction with the team and meetings. It is worth mentioning that, in addition to the consultations and home visits, other care activities were planned in the agenda, such as educational groups and reception of users.

Regarding supply indicators, of the pharmacist's weekly workload (40 hours), 5 hours were allocated for consultations and 8 hours for home visits, corresponding to $12.5 \%$ and $20.0 \%$ of the workload, respectively. Analyzing productivity, an average of 11.9 pharmaceutical consultations per month were performed in each facility, both specific and shared with other professionals. The average number of consultations was 19.5 per month, with an absenteeism rate of $39.2 \%(n=1,230)$. As for home visits, an average of 19.5 visits were scheduled per month, with around 17.2 visits/month and $11.5 \%$ of scheduled home visits were not performed because the patient was not at home at the time of the visit or refused care.

Regarding the identification of users serviced at pharmaceutical clinical services, which represents the demand indicator, approximately $73.5 \%(n=794)$ were referred by the health team, mainly doctors and nurses, $17.5 \%(n=189)$ were captured through active search of the pharmacist or pharmacy technician, based on previously established criteria, and only $9.0 \%(n=97)$ originated from self-referrals, that is, people themselves sought the service.

During the study period, 3,078 pharmacotherapyrelated problems were identified in 1,080 users, equivalent to 2.8 problems per patient. The most frequent problem was non-adherence to pharmacotherapy, mainly regarding the omission of doses and administration of medication at incorrect frequency.

From the identification of drug-associated problems, pharmaceutical interventions were carried out, which encompass the professional conduct before a diagnosis or evaluation and aimed to achieve the therapeutic goals 
and the prevention, identification and resolution of pharmacotherapy-related problems. Such interventions may be associated with specific guidelines on the drug, as well as referrals to other professionals, use of dosage guidance tools and specific treatment adaptations. A total of 6,862 interventions were performed on 1,080 patients, that is, 6.3 interventions per patient. A relationship with several interventions was standardized, allowing a quantitative survey on interventions, and the advice to the patient on drug treatment and non-pharmacological measures were the most recurrent, in $85.8 \%$ of users.

The evaluation of the clinical status of the most prevalent chronic conditions identified in the first, second and third pharmacological care was performed as a way of evaluating the therapeutic results that may be related to the use of drugs, as can be observed in Tables I and II. It is worth mentioning that hypertension and diabetes mellitus were the most frequent morbidities among patients treated at pharmaceutical services, with a rate of $80.1 \%(n=865)$ and $58.6 \%(n=633)$ of the patients, respectively.

\section{DISCUSSION}

The organization of the pharmacist's work through a model of an activity distribution agenda that contemplates the logistic-administrative and also assistance realms, as presented in the study, with a fair workload for each of these realms allows the development of a care model focused on the individual rather than on the product, as recommended by the National Pharmaceutical Assistance Policy (Brasil, 2004). The agenda with distribution of professional hours is an interesting alternative for the organization and linkage of pharmaceutical work, given the different demands and attributions under the responsibility of this professional.

Veber (2005) and Foppa et al. (2008) corroborate the incorporation of the pharmacist into PHC through actions geared to drugs, users and other health professionals, in order to contribute to an effective and safe drug treatment, reaffirming the importance of measuring these three instances of action in the pharmacist's routine. Araújo et al. (2008) and Araújo and Freitas (2006) discuss activities aimed at drug management as being more predictable and repetitive, in addition to being more associated with legal aspects, whereas actions directed at users encompass a direct integration with the patient and through the involvement with other health professionals, in which the main focus are the results deriving from the use of pharmacotherapy.

Among the care activities planned in the agendas of the pharmacists of the study, we highlight pharmaceutical consultations and home visits, which were used as supply indicators variables for the pharmaceutical clinical services of the territory. Five weekly hours were foreseen for pharmaceutical consultations and eight weekly hours for home visits, equivalent to $12.5 \%$ and $20 \%$ of the total workload, respectively. This supply pattern was used by all facilities, regardless of the complexity of the service and teams' size. However, this would be adapted after a period of evaluation by the local managers of each facility.

The pharmacist's work with users is pointed out as an important strategy for the resolution of PHC and the promotion of the rational use of drugs. Soler et al. (2010) state that the pharmacist's clinical involvement supports and cooperates with health promotion and prevention actions. However, while the presence of the pharmacist in

TABLE I - Proportion of arterial hypertension control in the first, second and third pharmaceutical care in the city of São Paulo from May to November 2016

\begin{tabular}{lccc}
\hline Clinical control profile & \% first care $(\mathbf{n}=\mathbf{8 6 5})$ & \% second care $(\mathbf{n}=\mathbf{4 4 2})$ & \% third care $(\mathbf{n}=\mathbf{1 0 9})$ \\
\hline Controlled & 10.1 & 39.1 & 50.5 \\
Non-controlled & 16.3 & 29.9 & 31.2 \\
Unknown & 73.6 & 31.0 & 18.3 \\
\hline
\end{tabular}

TABLE II - Proportion of Diabetes Mellitus control in the first, second and third pharmaceutical care in the city of São Paulo from May to November 2016

\begin{tabular}{lccc}
\hline Clinical control profile & \% first care $(\mathbf{n}=\mathbf{6 3 3})$ & \% second care $(\mathbf{n}=\mathbf{3 4 6})$ & \% third care $(\mathbf{n}=\mathbf{8 9})$ \\
\hline Controlled & 5.5 & 24.3 & 25.8 \\
Non-controlled & 31.0 & 52.0 & 65.2 \\
Unknown & 63.5 & 23.7 & 9.0 \\
\hline
\end{tabular}


PHC is already a reality in the country, the development of technical activities aimed at drug logistics and supplies availability (Canto, 2016) is still predominant. In a survey carried out in the south of the country with pharmacists working at the Family Health Support Center (NASF) in 2013 , it was identified that $80 \%$ of the pharmacist's total workload was focused on administrative activities and a small portion on care activities (Brasil, 2014c).

Within the scope of the Municipal Health Secretariat of São Paulo, Ordinance No 1918/2016 establishes some guidelines that guide PHC pharmacists' need to distribute their activities, so as to reconcile clinical and care and logistic actions, but there is no standard agenda model for the different care modalities nor specific parameters that support the distribution of the workload of pharmacist's activities in this level of health care (São Paulo, 2016c).

The introduction of the pharmacist in the context of PHC has been configured in order to build an identity based on new practices that transcend the availability of the pharmacological supplies and whose basic and essential foundation is reduced morbidity and mortality risks and the rational use of drugs. The setting of healthy public policies and the establishment of favorable promotional environments thus require professional skills, including in the pharmaceutical area, which exceed technical capacity, but which must also be political and understand all inherent aspects of human beings (Leite, 2007; Vieira, 2007).

From the data of the pharmaceutical services evaluated, we can infer that the greater number of home visits is due to the configuration of the pharmacist's agenda, which foresees a greater offer of this type of activity to the detriment of the consultations scheduled at the health facilities. One of the technologies for interaction in health care, mainly used in PHC, is home visit, which prioritizes the diagnosis of the individual's reality and the development of educational actions, through the establishment of links and by understanding the important aspects of the dynamics of family relationships, which directly influence the individual illness process. Thus, home care is a fundamental intervention tool in the context of family health and is included in the programmatic agenda of professionals working in the ESF, in order to subsidize interventions and the planning of health actions according to the way of life and resources available in the territory (Foppa et al., 2008; Albuquerque, Bosi, 2009; Giacomozzi, Lacerda, 2006).

Another highlight is the rate of first-time and return visits. The size of these services may vary according to some variables, such as: users' profile on the need for a short-term return, according to the care plan elaborated in the first attendance, recent incorporation of clinical pharmaceutical services in the territory and the evaluation period. As planned in the agenda, each first-time pharmaceutical appointment had an average duration of one hour and a return of 40 minutes, whereas home visits were scheduled at 1 hour per patient. Thus, each pharmacist had a weekly program of at least 5 consultations and 8 home visits, which were scheduled in advance with the team. This was the standard scope of pharmaceutical agenda in the territory, but the number of patients scheduled for first time and return visits was different between facilities and depended on local management, according to the aforementioned variables.

With respect to absenteeism in the pharmaceutical consultations, it indicates the non-attendance of approximately 4 out of 10 scheduled patients. Santos (2008) states that the estimate of the absenteeism rate in procedures and consultations in the SUS ranges from 22 to $30 \%$. However, in a study conducted in João Pessoa/ $\mathrm{PB}$, where the absenteeism rate in some UBS with ESF $(n=26)$ of a district was evaluated, the percentage of nonattendance in consultations in the facilities ranged from $24 \%$ to $41 \%$ (Cavalcanti et al., 2013). It is important to critically assess the absenteeism rate per facility, since it is multi-causal and may be related to territory characteristics, as well as to the linkage of the population with the facility and health professionals. In the case of pharmaceutical consultations, absenteeism may be related to the type of service offered, the acceptance and sensitization of the population, the effectiveness of the service itself and especially the recent onset of supply of pharmaceutical consultation services in the territory.

The rate of non-performance of scheduled home visits is lower than that of absenteeism in the consultations and is mainly related to the resident's absence at the time of the visit. Generally, the pharmacist is accompanied by the community health worker, who already has a link with the population and knows the routine of the community, favoring the accomplishment of visits. Some important strategies for the reduction of absenteeism in EFS have been listed, such as prior notice by the community worker and the telephone contact to confirm care (Ferreira et al., 2016a; Cavalcanti et al., 2013). In addition, it is worth mentioning the need to establish parameters that define acceptable limits of absenteeism in the national health policy in order to contribute to a better monitoring and evaluation of this event (Cavalcanti et al., 2013).

With regard to the listed demand indicator, which portrays the identification of users for pharmaceutical clinical care, a large portion was referred by the team and $17.5 \%$ resulted from active search. In a study carried 
out in the city of Curitiba, the capture of patients for the pharmaceutical consultation from the referral of other professionals was $55.6 \%$, while active search had a rate of $43.6 \%$ in the first three months of the onset of pharmaceutical consultations (Brasil, 2014c). Hence, it is possible to demonstrate good acceptance of the pharmaceutical clinical services by the other professionals of the health team in order to show the possibility of an integrated and resolutive work. However, it is worth noting that before the start of the pharmaceutical consultations in the evaluated region, all facility professionals were sensitized, in addition pharmacists participate daily in team meetings to discuss and provide feedback on the referred cases. These factors may also justify the fact that almost all the vacancies of pharmaceutical consultations supplied (20 hours consultations/month) were fully booked, some 19.5 hours scheduled consultations/month, which shows a demand for this type of service.

However, this is not the case with pharmaceutical home visits, since 32 hours of visits/month were offered and only 19.46 hours of visits/month were filled. Giacomozzi and Lacerda (2006) describe that some difficulties related to the implementation of home care in the ESF are mainly due to the supply structure and also to professional training. We can think of a possible difficulty of securing patients by the pharmacist for this type of service, which may be associated both to the team and to specific questions of the pharmaceutical professionals, such as insecurity as to the development of this type of activity, deficient training and even difficulty in untying pharmacy's physical space in the facility, which makes it hard to leave the room for visits in the territory.

The matrix support and the incorporation of an inclusive stance of the pharmacist with the team in the shared responsibility of patients are fundamental processes. The pharmacist often faces hardships in inserting and integrating with the team in PHC, because he cannot clearly understand his duties in this context, thus generating a professional insecurity in the area of operation, which impairs the consolidation of his work and the recognition of his activities (De Castro, Quevedo, 2014).

The profile of patients who underwent clinical pharmacological care during the study period was mostly female over 60 years of age. In addition, according to priority criteria established for referral to the pharmacist, they used five or more medications and had two or more chronic comorbidities. This profile characterizes users who use health services more frequently and are subject to more vulnerable situations caused by medications or worsening of chronic conditions.
It is worth noting that the profile of an elderly user necessarily has greater difficulties in the use of drugs (Field et al., 2007), as evidenced in the study, in which $40 \%$ of the patients had no autonomy in the administration of drugs due to potential weaknesses related to sensory and memory organs. Nevertheless, only $21 \%$ of users have a health care caregiver, which may directly interfere with the results of pharmacotherapy. Studies indicate that it is common to identify problems associated with medications in the elderly, especially regarding inappropriate prescriptions in basic care, contributing to the increase of hospital admissions (Riordan et al., 2016).

The development of clinical services is primarily aimed at improving the results from the use of a drug therapy, from the prevention, identification and resolution of drug-related problems through the implementation of pharmaceutical interventions that may be associated to the patient or to another healthcare professional. Hence, it is fundamental to understand pharmacotherapy-related processes, ranging from the selection of pharmacological treatment to the manifestation of therapeutic results in the body (Foppa et al., 2008; Correr, Otuki, 2013).

With reference to service process indicators, the identification of pharmacotherapy-related problems is part of the evaluation scope of the pharmacist who, from the patient's anamnesis and pharmacotherapy review identifies the real or potential problems associated with the drug (Correr, Otuki, 2013; Brasil, 2014b). We found an average of 2.85 pharmacotherapy-related problems per patient in the study period, and the predominant userrelated problem was non-adherence to drug treatment.

In a study carried out in Goiânia with hypertensive patients, we identified 10.1 drug-related problems per patient, and the most recurrent problem was ineffective treatment, and non-adherence was only the fourth most common issue (Martins et al., 2013). In a study conducted by Alano, Correa and Galato (2012) with patients monitored in a pharmaceutical care service of Santa Catarina, an average of 2.7 problems per patient were identified and the most common were related to the drugs' effectiveness and safety. Thus, it is possible to perceive that the proportion of pharmacotherapy-related problems per patient is variable, since it depends on the selection criteria of patients and their characteristics, the number of medications used and the methodology for quantifying the types of problems. However, some studies have shown that the use of a greater number of drugs leads to a higher frequency of errors of users related to their pharmacotherapy (Field et al., 2007).

An average of 6.35 pharmaceutical interventions per patient was performed and counseling was predominant. 
As in other studies, verbal pharmaceutical orientation mainly related to drug treatment is the most recurrent in pharmaceutical clinical care (Martins et al., 2013; Ferreira et al., 2016b). Patients' lack of knowledge about the medications used may result in poor adherence and negative therapeutic outcomes, so pharmaceutical counseling becomes critical for users' empowerment regarding their medications and greater pharmacotherapy success (Oenning, Oliveira, Blatt, 2011). Studies have shown that the elderly usually receive the highest number of pharmaceutical interventions in clinical care (Ferreira et al., 2016b), probably due to possible complexities in treatment, such as high number of medications and comorbidities.

PHC is fundamental since it is the main gateway to the state health care system in our country, it thus plays a relevant role in responding to a large part of the population's demand. In Brazil, about 60 to $80 \%$ of hypertension and diabetes cases can be treated and prevented at this level of care. From then on, it is possible to perceive the effective resolution capacity of this PHC, defined as a technologically specific form of health care, establishing itself through the synthesis of knowledge and complex integration of individual and collective actions, with curative, preventive, care-related and educational purposes (Araújo, Pereira, Freitas, 2008; Pereira, Freitas, 2008; Carvalho et al., 2012).

In this perspective, the control profile of the most prevalent chronic health conditions was evaluated in the patients who underwent pharmaceutical care, as a way of evidencing the therapeutic results that may be related to the use of drugs and resolution of the clinical services provided to the population. The most frequently diagnosed chronic conditions were hypertension and diabetes mellitus, due to the type of patient attended and the prevalence of these diseases in society. Control parameters were observed based on the definition of therapeutic goals, due to the established clinical protocols, and the accomplishment of laboratory tests and clinical monitoring.

It is interesting to note that the first pharmaceutical care is characterized by a high rate of lack of knowledge of therapeutic results of chronic comorbidities hypertension and diabetes due to the lack of clinical parameters and laboratory tests that attest the current clinical status of these problems. The increasing number of treatments reduces the unknown clinical status and increases the controlled and non-controlled parameters, probably due to the effectiveness of pharmaceutical intervention related to the recommendation to monitor blood pressure and blood glucose.

A study carried out in Curitiba also showed a considerable number of patients who, in the first pharmaceutical care, have unknown therapeutic results regarding their health conditions, namely, about $57 \%$ of hypertensive patients and $31 \%$ of diabetics (Brazil, $2014 \mathrm{c}$ ). The therapeutic goal to be achieved is always the compensation of the patient, that is, achieving the ideal clinical indicators established for each health condition and to keep the patients in a controlled clinical status. However, it is important to emphasize that achieving positive therapeutic results, especially with regard to chronic comorbidities, also involves non-drug parameters such as healthy lifestyle habits, which should also be worked by pharmacists and other team members with the patient. Results demonstrate the importance of pharmaceutical clinical services in achieving concrete results for the health indicators of the population.

Studies have shown an important contribution of the pharmacist with regard to the care associated with chronic diseases, mainly regarding the improvement of the selfmanagement of medications, resulting in improvements in the chronic health conditions of hypertensive and diabetic patients, as well as with psychiatric comorbidities (Dolovich et al., 2008; Rotta et al., 2015).

Thus, pharmacists play an important role in working jointly with the PHC team, promoting a rational use of pharmacotherapy, as well as contributing to effective and safe results in the use of medicines aimed at health conditions and comorbidities more frequent in the community (Alano, Correa, Galato, 2012; Martins et al., 2013).

\section{CONCLUSIONS}

The implementation of an agenda, which allows the proper sizing of pharmaceutical activities' workload according to local needs and the characteristics of the health facility enables the reorganization of the work process of this professional, in order to add logistic-administrative and clinical-care actions, which focus not only on the drug, but also on patients and other professionals.

There is evidence of a good team acceptance regarding the development of pharmaceutical clinical services in the facilities, since most patients attended in the pharmaceutical consultations and home visits were referred by other health professionals. In this same perspective, all vacancies for pharmaceutical consultations supplied were practically filled, demonstrating a balance between supply and demand of this activity, which was not case of home visits, due to fewer scheduled visits against vacancies available. The rate of absenteeism in pharmaceutical consultations is a relevant problem that must be managed in the service analysis process. 
Among the pharmacotherapy-related problems identified in pharmaceutical consultations, the most frequent was non-adherence to drug treatment, and, consequently, advice on pharmacotherapy and healthy life habits was the most frequent pharmaceutical intervention performed on patients. Patient follow-up through consultations and home visits to pharmaceutical products contributed to a better understanding of the control profile of the most prevalent health conditions and the gradual development of therapeutic results associated with the use of drugs.

\section{REFERENCES}

Alano GM, Correa TS, Galato D. Indicadores do Serviço de Atenção Farmacêutica (SAF) da Universidade do Sul de Santa Catarina. Ciênc Saúde Coletiva. 2012;17(3):757-764.

Albuquerque ABB, Bosi MLM. Visita domiciliar no âmbito da Estratégia Saúde da Família: percepções de usuários no Município de Fortaleza, Ceará, Brasil. Cad Saúde Pública. 2009;25(5):1103-1112.

Araújo ALA, Freitas O. Concepções do profissional farmacêutico sobre a assistência farmacêutica na unidade básica de saúde: dificuldades e elementos para a mudança. Rev Bras Cienc Farm. 2006;42(1):137-146.

Araújo ALA, Pereira LRL, Ueta JM, Freitas O. Perfil da assistência farmacêutica na atenção primária do Sistema Único de Saúde. Ciênc Saúde Coletiva. 2008;13(Supl):611-617.

Brasil. Ministério da Saúde. Conselho Nacional de Saúde. Resolução CNS n 338 de 06 de maio de 2004. Aprova a Política Nacional de Assistência Farmacêutica. Diário Oficial da União, Poder Executivo, Seção 1 n.96, 20 de maio de 2004. Brasília: Ministério da Saúde, 2004.

Brasil. Ministério da Saúde. Secretaria de Ciência, Tecnologia e Insumos Estratégicos, Departamento de Assistência Farmacêutica e Insumos Estratégicos. Serviços Farmacêuticos na Atenção Básica à Saúde (Cuidado farmacêutico na Atenção Básica, caderno 1). Brasília: Ministério da Saúde; 2014a. 108p.

Brasil. Ministério da Saúde. Secretaria de Ciência, Tecnologia e Insumos Estratégicos, Departamento de Assistência Farmacêutica e Insumos Estratégicos. Capacitação para implantação dos Serviços de Clínica Farmacêutica (Cuidado farmacêutico na Atenção Básica, caderno 2). Brasília: Ministério da Saúde; 2014b. 308p.
Brasil. Ministério da Saúde. Secretaria de Ciência, Tecnologia e Insumos Estratégicos, Departamento de Assistência Farmacêutica e Insumos Estratégicos. Resultados do projeto de implantação do Cuidado Farmacêutico no município de Curitiba. (Cuidado farmacêutico na Atenção Básica, caderno 4). Brasília: Ministério da Saúde; 2014c. 100p.

Canto VB. Implementação de um Serviço de Clínica Farmacêutica em uma Unidade Básica de Saúde (UBS) do município de Florianópolis: Um Relato de Experiência. Florianópolis: Universidade Federal de Santa Catarina, Centro de Ciências da Saúde; 2016. [Acessado em: 30 de nov. de 2016]. Disponível em: https://repositorio.ufsc.br/ handle/123456789/168893.

Carvalho ALM, Leopoldino RWD, Silva JEG, Cunha CP. Adesão ao tratamento medicamentoso em usuários cadastrados no Programa Hiperdia no município de Teresina (PI). Ciênc Saúde Coletiva. 2012;17(7):1885-1892.

Cavalcanti RP, Cavalcanti JCM, Serrano RMSM, Santana PR. Absenteísmo de consultas especializadas nos sistema de saúde público: relação entre causas e o processo de trabalho de equipes de saúde da família, João Pessoa-PB, Brasil. Tempus Actas Saúde Coletiva. 2013;7(2):63-84.

Correr CJ, Otuki MF. A Prática Farmacêutica na Farmácia Comunitária. Porto Alegre: Artmed; 2013. 454p.

De Castro CCH, Quevedo MP. O farmacêutico e a promoção da saúde: uma união possível na prática? Infarma Ciênc Farm. 2014;26(3):140-148.

Dolovich L, Pottie K, Kaczorowski, J, Farrell B, Austin Z, Rodriguez C, Sellors C. Integrating family medicine and pharmacy to advance primary care therapeutics. Clin Pharmacol Ther. 2008;83(6):913-917.

Ferreira, MB, Lopes AC, Lion MT, Lima DC, Nogueira DA, Pereira AA. Absenteísmo em consultas odontológicas programáticas na Estratégia Saúde da Família. Rev Univ Vale do Rio Verde. 2016a;14(1):411-419.

Ferreira TXAM, Prudente LR, Dewulf NLS, Provin MP, Mastroianni PC, Silveira EA, et al. Medication dispensing as an opportunity for patient counseling and approach to drug-related problems. Braz J Pharm Sci. 2016b;52(1):151-162.

Field TS, Mazor KM, Briesacher B, Debellis KR, Gurwitz JH. Adverse drug events resulting from patient errors in older adults. J Am Geriatr Soc. 2007;55(2):271-6. 
Foppa AA, Bevilacqua G, Pinto LH, Blatt CR. Atenção farmacêutica no contexto da estratégia de saúde da família. Rev Bras Ciênc Farm. 2008;44(4):727-737.

Funchal-Witzel MDR, Castro LLC, Romano-Lieber NS, Narvai PC. Brazilian scientific production on pharmaceutical care from 1990 to 2009. Braz J Pharm Sci. 2011;47(2):409-420.

Gastelurrutia MA, Fernández-Llimós F, García-Delgado P, Gastelurrutia AP, Faus MJ, Benrimoj SI. Barreras y facilitadores para la diseminación e implantación de servicios cognitivos de la farmacia comunitaria española. Seguimiento Farmacoter. 2005;3(2):65-77.

Giacomozzi CM, Lacerda MR. A prática da assistência domiciliar dos profissionais da estratégia de saúde da família. Texto Contexto Enferm. 2006;15(4):645-653.

Leite SN. Quê "promoção da saúde"? Discutindo propostas para a atuação do farmacêutico na promoção da saúde. Ciênc Saúde Coletiva. 2007;12(6):1749-1750.

Loch-Neckel G, Crepaldi MA. Pharmacist contributions for basic care from the perspective of professionals of familial health care teams. Braz J Pharm Sci. 2009;45(2):263-272.

Martins BPS, Aquino AT, Provin MP, Lima DM, Dewulf NLS, Amaral RG. Pharmaceutical Care for hypertensive patients provided within the Family Health Strategy in Goiânia, Goiás, Brazil. Braz J Pharm Sci. 2013;49(3):609-618.

Oliveira AB, Oyakawa CN, Miguel MD, Zanin SMW, Montrucchio DP. Obstáculos da atenção farmacêutica no Brasil. Rev Bras Cienc Farm. 2005;41(4):409-413.

Oenning D, Oliveira BV, Blatt CR. Conhecimento dos pacientes sobre os medicamentos prescritos após consulta médica e dispensação. Ciênc Saúde Coletiva. 2011;16(7):3277-3283.

Pereira LRL, Freitas O. A evolução da Atenção Farmacêutica e a perspectiva para o Brasil. Rev Bras Cienc Farm. 2008;44(4):601612.

Riordan DO, Walsh KA, Galvin R, Sinnott C, Kearney PM, Byrne S. The effect of pharmacist-led interventions in optimising prescribing in older adults in primary care: a systematic review. SAGE Open Med. 2016;4:PMID27354917.
Roberts AS, Hopp T, Sorensen EW, Benrimoj SI, Chen TF, Herborg H. Understanding practice change in community pharmacy: a qualitative research instrument based on organizational theory. Pharm World Sci. 2003;25(5):227-34.

Rotta I, Salgado TM, Silva ML, Correr CJ, FernandezLlimos F. Effectiveness of clinical pharmacy services: an overview of systematic reviews (2000-2010). Int J Clin Pharm. 2015;37(5):687-697.

Santos JS. Absenteísmo dos usuários em consultas e procedimentos especializados no agendados no SUS: um estudo em um município baiano. [Dissertação]. Vitória da Conquista: Universidade Federal da Bahia, Instituto de Saúde Coletiva; 2008.

São Paulo. Portal da Prefeitura Municipal de São Paulo [internet]. Dados demográficos dos distritos pertencentes às subprefeituras. Disponível em: <www.prefeitura.sp.gov.br/cidade/secretarias/ subprefeituras/subprefeituras/dados_demograficos/index. php? $p=12758>$. Acessado em: 30 nov. 2016 .

São Paulo. Portal da Prefeitura Municipal de São Paulo. Sistema de Localização de Estabelecimentos de Saúde da Rede SUS do Município de São Paulo. Disponível em: http://buscasaude. prefeitura.sp.gov.br/. Acesso em: 30 nov. 2016 b.

São Paulo. Secretaria Municipal de Saúde de São Paulo. Portaria n. 1918, de 27 de outubro de 2016. Institui o Cuidado Farmacêutico na rede de atenção básica e de especialidades da SMS SP. Diário Oficial da Cidade de São Paulo, São Paulo, SP, 27 out. 2016. p. 17 e 18. 2016 c.

Sociedades Brasileiras de Cardiologia, Hipertensão e Nefrologia. V Diretrizes Brasileiras de Monitorização Ambulatorial da Pressão Arterial (MAPA V) e III Diretrizes Brasileiras de Monitorização Residencial da Pressão Arterial (MRPA III). Arq Bras Cardiol. 2011;97(3 Supl 3):1-24.

Sociedade Brasileira de Diabetes. Diretrizes da Sociedade Brasileira de Diabetes: 2014-2015. São Paulo: AC Farmacêutica; 2015.

Soler O, Rosa MB, Fonseca AL, Fassy MF, Machado MC, Silva RMC. Assistência farmacêutica clínica na atenção primária à saúde por meio do programa saúde da família. Rev Bras Farm. 2010;91(1):37-45. 
Pharmaceutical clinical services in basic care in a region of the municipality of São Paulo

Varela CA, Matsumoto C Y. Política pública inovadora de geração de renda e desenvolvimento local: o caso da Câmara de Animação Econômica da Subprefeitura do Itaim Paulista (CAEIT), São Paulo, Brasil. Rev Adm Públ. 2012;46(4):1059-1079.

Veber AP. A atuação do farmacêutico na saúde da família. In: Cordeiro BC, Leite SN (Org.). O farmacêutico na Atenção à Saúde. Itajaí: Ed. da Univali; 2005. p. 53-70.
Vieira FS. Possibilidades de contribuição do farmacêutico para a promoção da saúde. Ciênc. saúde coletiva. 2007;12(1):213-220.

Received for publication on $23^{\text {th }}$ August 2017 Accepted for publication on $16^{\text {th }}$ April 2018 